\title{
Barrier Island Shorelines Extracted from Landsat Imagery
}

By Kristy K. Guy

Open-File Report 2015-1179

U.S. Department of the Interior

U.S. Geological Survey 


\section{U.S. Department of the Interior \\ SALLY JEWELL, Secretary}

\section{U.S. Geological Survey \\ Suzette M. Kimball, Acting Director}

U.S. Geological Survey, Reston, Virginia: 2015

For more information on the USGS-the Federal source for science about the Earth,

its natural and living resources, natural hazards, and the environment-visit

http://www.usgs.gov/ or call 1-888-ASK-USGS (1-888-275-8747).

For an overview of USGS information products, including maps, imagery, and publications, visit http://www.usgs.gov/pubprod/.

Any use of trade, firm, or product names is for descriptive purposes only and does not imply endorsement by the U.S. Government.

Although this information product, for the most part, is in the public domain, it also may contain copyrighted materials as noted in the text. Permission to reproduce copyrighted items must be secured from the copyright owner.

Suggested citation:

Guy, K.K., 2015, Barrier island shorelines extracted from Landsat imagery: U.S. Geological Survey Open-File Report 2015-1179, 3 p., http://dx.doi.org/10.3133/ofr20151179.

ISSN 2331-1258 (online) 


\section{Contents}

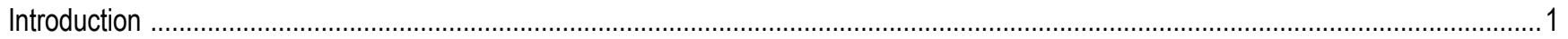

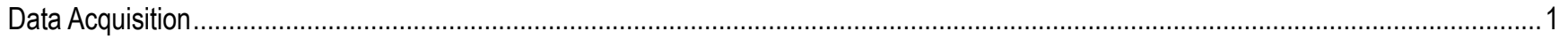

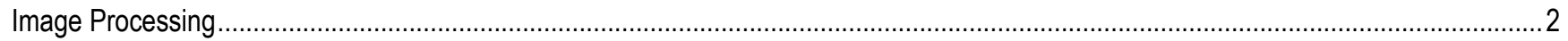

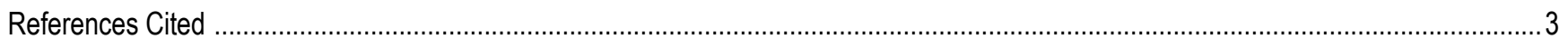

\section{Figures}

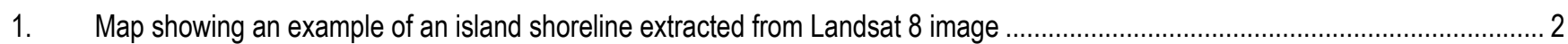




\section{Conversion Factors}

International System of Units to Inch/Pound

\begin{tabular}{lll}
\hline \multicolumn{1}{c}{ Multiply } & By & \multicolumn{1}{c}{ To obtain } \\
\hline & Length & \\
\hline millimeter $(\mathrm{mm})$ & 0.03937 & inch (in.) \\
meter $(\mathrm{m})$ & 3.281 & foot (ft) \\
\hline
\end{tabular}

\section{Datum}

Horizontal coordinate information is referenced to World Geodetic System 1984, Universal Transverse Mercator Zone 16N.

\section{Abbreviations}

$\begin{array}{ll}\text { EROS } & \text { Earth Resources Observation and Science Center } \\ \text { ETM+ } & \text { Enhanced Thematic Mapper Plus } \\ \text { lidar } & \text { light detection and ranging } \\ \text { MLLW } & \text { Mean Lower Low Water } \\ \text { OLI } & \text { Operational Land Imager } \\ \text { TM } & \text { Thematic Mapper } \\ \mu m & \text { micrometer }\end{array}$




\title{
Barrier Island Shorelines Extracted from Landsat Imagery
}

\author{
By Kristy K. Guy
}

\section{Introduction}

Changes to barrier islands occur at time scales that vary from the few hours it takes an individual storm to pass (Morton, 2008) to the millennia it takes for coastal systems to undergo geologic evolution. Developing an understanding of how barrier islands will respond to climate change, sea level rise, and major storms over a range of time scales is relevant to studies of physical, geological, ecological, and societal processes and will help to guide and improve management of our coastal resources (Sallenger and others, 1987). Observations of coastal processes made over a range of spatial and temporal scales and from a variety of instrument platforms (for example, in situ and remote sensing) are required to understand and eventually predict the evolution of coastal systems.

The deployment of Landsat and other earth-observing satellites within the last few decades has provided an opportunity to observe barrier islands at frequent intervals, often many times a year. This sample frequency is much higher and the spatial coverage much greater than most routine high-resolution topographic surveys (Guy and others, 2014). In addition, the historical record of these datasets have become long enough to document shorter- (that is, annual) and longer-term (that is, decadal) changes from a single data source. Certain aspects of barrier island morphology, such as island size, shape, and position, can be determined from these images and can indicate erosion, land loss, and island breakup (McBride and others, 1989; Plant and Guy, 2013).

The shoreline is a common variable used as a metric for coastal erosion or change (Himmelstoss and others, 2010). Although shorelines are often extracted from topographic data (for example, groundbased surveys and light detection and ranging [lidar]), image-based shorelines, corrected for their inherent uncertainties (Moore and others, 2006), have provided much of our understanding of long-term shoreline change because they pre-date routine lidar elevation survey methods. Image-based shorelines continue to be valuable because of their higher temporal resolution compared to costly airborne lidar surveys. A method for extracting sandy shorelines from 30-meter (m) resolution Landsat imagery is presented here.

\section{Data Acquisition}

Landsat 5 Thematic Mapper (TM), Landsat 7 Enhanced Thematic Mapper Plus (ETM+), and Landsat 8 Operational Land Imager (OLI) satellite imagery are acquired in digital format from the U.S. Geological Survey Earth Resources Observation and Science Center (EROS) Global Visualization Viewer (http://glovis.usgs.gov/). Images are selected on the basis of cloud-free areas of interest. Landsat 7 ETM+ images acquired after May 2003 are not used due to striping caused by the failure of the instrument's scan-line corrector. 


\section{Image Processing}

The Landsat images are processed using $\mathrm{ESRI}^{\circledR}$ ArcMap $^{\mathrm{TM}}$ and ArcCatalog ${ }^{\mathrm{TM}}$. The images are subset (trimmed) to the area of interest, and isolines are generated on the basis of the numerical values of band 7. Band 7, an infrared band (2.08-2.35 micrometers $(\mu \mathrm{m})$ for TM, 2.09-2.35 $\mu \mathrm{m}$ for ETM+, 2.11-2.29 $\mu \mathrm{m}$ for OLI), clearly distinguishes land from water because of the absorption of the wavelengths by water (Lillesand and Kiefer, 1987), resulting in a low reflectance in contrast to the higher reflectance of land areas, particularly sand (fig. 1). The isolines are visually examined with their corresponding images, and the isoline that best represents the land/water line for each image is selected to represent the shoreline. Wet, marshy shorelines are less reliably delineated using this method and vary more with tide level than sandy shorelines. When necessary, small edits are made by hand to the selected isolines. The selected isolines are then converted to polygon shapefiles. Small polygons found within the main island perimeter generally represent surface water. Polygon areas are calculated and added to the polygon attribute tables. Predicted tide levels relative to mean lower low water (MLLW) from a nearby tide station are obtained from a tide and current prediction program and added as an attribute to the line and polygon shapefiles. No adjustments are made to the shorelines for varying tide levels.

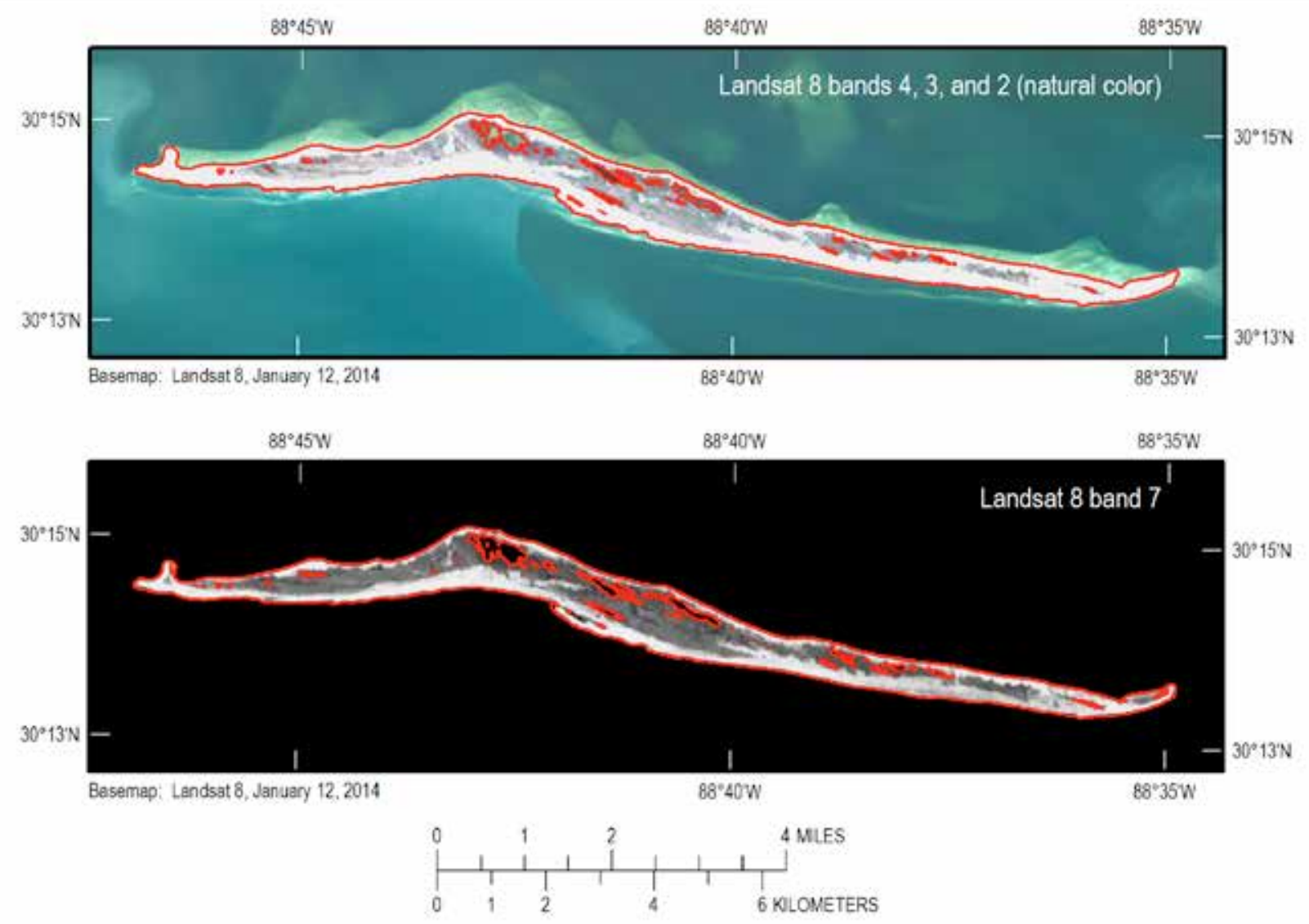

Figure 1. Map showing an example of an island shoreline extracted from Landsat 8 image. The top map shows bands 4, 3, and 2 (simulating natural color) of a Landsat 8 image of Horn Island, Mississippi, collected January 12, 2014, and the shoreline (red line) extracted from it. The water, suspended sediments, and shallow sea bottoms are visible. The bottom map shows band 7 of the same image with the same shoreline. The water is black and land areas, particularly sandy beaches, are distinct. The method described here uses band 7 for extracting the shoreline. 


\section{References Cited}

Guy, K.K., Plant, N.G., and Bonisteel-Cormier, J.M., 2014, Topographic lidar survey of the Chandeleur Islands, Louisiana, February 6, 2012: U.S. Geological Survey Data Series 840, accessed March 9, 2015, at http://dx.doi.org/10.3133/ds840.

Himmelstoss, E.A., Kratzmann, M., Hapke, C., Thieler, E.R., and List, J.H., 2010, The national assessment of shoreline change-A GIS compilation of vector shorelines and associated shoreline change data for the New England and Mid-Atlantic coasts: U.S. Geological Survey Open-File Report 20101119, accessed March 9, 2015, at http://pubs.er.usgs.gov/publication/ofr20101119.

Lillesand, T.M., and Kiefer, R.W., 1987, Remote sensing and image interpretation (2d ed.): New York, John Wiley \& Sons, p. 17-18.

McBride, R.A., Penland, S., Jaffe, B., Williams, S.J., Sallenger, A.H., Jr., and Westphal, K.A., 1989, Erosion and deterioration of the Isles Dernieres barrier island arc, Louisiana, U.S.A._-1853 to 1988 : Gulf Coast Association of Geological Societies Transactions, v. 39, p. 431-444, accessed March 9, 2015, at http://archives.datapages.com/data/gcags/data/039/039001/0431.htm.

Moore, L.J., Ruggiero, P., and List, J.H., 2006, Comparing mean high water and high water line shorelines-Should proxy-datum offsets be incorporated into shoreline change analysis?: Journal of Coastal Research, v. 22, no. 4, p. 894-905.

Morton, R.A., 2008, Historical changes in the Mississippi-Alabama barrier-island chain and the roles of extreme storms, sea level, and human activities: Journal of Coastal Research, v. 24, no. 6, p. 1587-1600, accessed March 9, 2015, at http://ngom.usgs.gov/pubs/pubs/Morton_MSALBarriers_JCR_09.pdf.

Plant, N.G., and Guy, K.K., 2013, Change in the length of the middle section of the Chandeleur Islands Oil berm, November 17, 2010, through September 6, 2011: U.S. Geological survey Open-File Report 2013-1075, 11 p., accessed March 9, 2015, at http://pubs.er.usgs.gov/publication/ofr20131075.

Sallenger, A.H., Jr., Penland, S., Williams, S.J., and Suter, J.R., 1987, Louisiana barrier island erosion study [abs.]: Coastal Sediments '87, Proceedings of a Specialty Conference on Advances in Understanding of Coastal Sediment Processes, New Orleans, La., accessed March 9, 2015, at http://pubs.er.usgs.gov/publication/70015228. 
